\title{
UPAYA MENINGKATKAN HASIL BELAJAR IPA PADA MATERI TEKANAN ZAT MELALUI PENERAPAN MODEL PROBEX
}

\author{
NURHASANAH \\ Pascasarjana PMIPA, Universitas Indraprasta PGRI, Jakarta \\ e-mail: nana.alhamid45@gmail.com
}

\begin{abstract}
ABSTRAK
Penelitian tindakan kelas ini bertujuan untuk meningkatkan hasil belajar IPA pada teori pokok tekanan pada zat cair siswa kelas 8.A MTs Al Hamid Jakarta Tahun Pelajaran 2019/2020 melalui penerapan model PROBEX. Metode penelitian yang digunakan adalah penelitian tindakan kelas dengan empat tahap dasar yang saling terkait dan berkesinambungan, yaitu Planning (Rencana), Action (Tindakan), Observasi (pengamatan), Reflection (refleksi) yang dirancang dalam 2 siklus. Subjek penelitian ini adalah siswa kelas 8.A Tahun Pelajaran 2019/2020 yang berada di Madrasah Tsanawiyah Al Hamid Jakarta. Jumlah subyek penelitian 25 siswa. Hasil penelitian menyimpulkan bahwa Penerapan Model PROBEX dapat meningkatkan hasil belajar IPA pada materi pokok Tekanan Zat pada siswa kelas 8.A MTs Al Hamid Jakarta Timur Tahun Pelajaran 2019/2020, yaitu sebelum perbaikan ketuntasan hanya $32 \%$, setelah siklus I mencapai $64 \%$ dan setelah pelaksanaan siklus II mencapai $92 \%$.
\end{abstract}

Kata Kunci: hasil belajar IPA, tekanan zat cair, penerapan model probex.

ABSTRACT

This classroom action research aims to improve science learning outcome on the basic theory of pressure in liquid for 8th grade students of MTs Al Hamid Jakarta for the academic year of 2019/2020 through the application of the PROBEX model. The research method used is classroom action research with four basic steps which are interrelated and sustainable, namely Planning, Action, Observation, Reflection which are designed in 2 cycles. The subject of this study is 8th grade students for the academic year of 2019/2020 at Madrasah Tsanawiyah Al Hamid Jakarta. The amount of research subject is 25 students. The result of the study concluded that the application of the PROBEX Model could improve science learning outcome on the main subject of Liquid Substance Pressure in 8th grade students of MTs Al Hamid East Jakarta in the academic year of 2019/2020, namely: it was only 32\% before the completeness improvement, it reached $64 \%$ after the first cycle and it reached $92 \%$ after the implementation of the second cycle.

Keywords: science learning outcome, liquid substance pressure, application of the probex model.

\section{PENDAHULUAN}

Keberhasilan suatu proses belajar mengajar dipengaruhi oleh faktor internal dan faktor eksternal. Metode pembelajaran ada berbagai macam diantaranya adalah metode ceramah, metode eksperimen, metode diskusi, metode inkuiri, metode kooperatif dan sebagainya. Setiap metode pembelajaran mempunyai karakteristik tertentu dengan kelebihan dan kekurangan masing-masing.

Namun saat ini, umumnya guru menggunakan metode yang sama untuk setiap materi yaitu pembelajaran yang hanya menggunakan metode ceramah tersebut pembelajarannya dikatakan bersifat konvensional, karena selain sederhana dan mudah dilaksanakan, metode ini juga tidak memakan waktu banyak. Dalam pembelajaran konvensional siswa hanya mendengarkan dengan teliti serta mencatat hal-hal penting yang disampaikan guru, metode seperti ini memberikan kesan bahwa siswa cenderung hanya sebagai subyek dan membatasi siswa untuk berperan aktif dan kreatif dalam kegiatan belajar mengajar, selain itu pembelajaran konvensional seringkali menjadikan siswa jenuh dan enggan dalam menerima pelajaran. Sehingga tujuan pembelajaran yang telah ditetapkan tidak tercapai secara optimal. 


\section{EDUCATOR : Jurnal Inovasi Tenaga Pendidik dan Kependidikan Vol. 1 No. 2 Desember 2021, e-ISSN : 2807-8659 | p-ISSN : 2807-8829}

Pembelajaran IPA juga merupakan bagian dari pendidikan, pastinya pembelajarn IPA harus mengikuti kemajuan zaman yang ditandai dengan peningkatan kemajuan ilmu pengetahuan dan teknologi. Kemajuan ini membutuhkan berbagai faktor pendukung baik faktor fisik maupun nonfisik. Keberhasilan proses pembelajaran tidak hanya tergantung dari seberapa besar kemampuan dan kompetensi guru dalam mengajar tetapi juga keterlibatan siswa yang aktif dan kreatif.

Adapun yang menjadi penyebab rendahnya hasil belajar siswa yaitu kualitas pembelajaran yang masih rendah, guru kurang bervariasi dalam menggunakan strategi pembelajaran. Oleh karena itu, guru harus mampu menggunakan strategi pembelajaran yang dapat meningkatkan motivasi belajar siswa, agar prestasi hasil belajar siswa dapat optimal, yaitu dengan menggunakan strategi pembelajaran yang bervariasi dan merangsang berpikir anak. Guru sudah berupaya dengan menggunakan beberapa metode pembelajaran tetapi hasil ulangan harian tetap banyak siswa yang belum mencapai batas KKM. Dari hasil itu kiranya perlu strategi, metode atau cara yang dapat ditempuh agar prestasi belajar fisika pada konsep tekanan meningkat mencapai KKM yaitu dengan cara sebelum eksperimen dilihat prediksi siswa pada permasalahan tekanan dan setelah eksperimen, menjelaskan hasil eksperimen

Namun pengalaman penulis di lapangan, khususnya di kelas 8.A MTs Al Hamid Jakarta menunjukkan hal yang berbeda. Siswa kurang memperlihatkan ketertarikan terhadap materi pembelajaran Ilmu Pengetahuan Alam karena tidak melihat secara nyata konsep-konsep yang diajarkan. Siswakurang melihat hubungan antara materi IPA dengan kehidupannya sehari-hari, sehingga siswa kurang tertarik mempelajari IPA. Dan pada akhirnya nilai-nilai kuis, Ulangan Harian siswa menunjukkan pencapaian hasil yang mengecewakan, belum mencapai standar Kriteria Ketuntasan Minimal yang diharapkan. Nilai rata-rata hasil pembelajaran IPA di kelas 8.A MTs Al Hamid Jakarta hanya mencapai 58,1,terendah bila dibandingkan dengan mata pelajaran lain.

Rendahnya hasil belajar tersebut setelah ditelusuri antara lain disebabkan oleh beberapa faktor. Faktor dari guru, kurang bervariasi dalam penggunaan metode karena minimnya peralatan, dan terlalu sering menggunakan metode ceramah dan tanya jawab saja. Sedangkan faktor dari siswa, kurang melakukan eksperimen yang memadai untuk Kompetensi Dasar yang membutuhkan penalaran dan pembuktian konsep/teori karena kurang tersedianya peralatan eksperimen di sekolah. Akibatnya guru menyampaikan pembelajaran lebih banyak dengan pendekatan ekspositoris, sedangkan siswa hanya dijejali dengan konsep-konsep saja tanpa praktikum. Hal ini menjadikan siswa kesulitan menguasai materi IPA karena pembelajaran yang dilakukan belum mengakomodir secara optimal kebutuhan tersebut.

Pada umumnya materi pembelajaran IPA membutuhkan pembuktian dan pengalaman nyata bagi siswa dalam mempelajarinya. Pembuktian dan pengalaman nyata dalam belajar tersebut kurang efektif bila dilakukan dengan pendekatan ekspositorik seperti yang selama ini sering dilakukan guru. Untuk itu dibutuhkan metode yang tepat dalam memperoleh pengalaman nyata tersebut. Salah satu metode yang dapat digunakan untuk pemerolehan pengalaman belajar yang nyata bagi siswa adalah metode eksperimen. Karena metode eksperimen sebagai suatu metode pengembangan ilmu akan mampu merangsang sikap ilmiah siswa melalui percobaan sendiri secara sederhana, dan membuktikan kebenaran kata-kata yang selama ini diketahuinya tapi kurang difahami maknanya. Karena itu metode eksperimen merupakan salah satu metode yang cocok dilakukan dalam bentuk eksperimen sederhana. Sebagai suatu metode pengembangan ilmu, metode eksperimen patut diterapkan di sekolah-sekolah dasar agar mampumelaksanakan eksperimen sederhana. Pendekatan interaktif-konstruktivis menggunakan strategi mengajar. Predict-Observe-Explain (PROBEX) untuk menggalakkan belajar dan perolehan pengetahuan. Strategi ini memungkinkan peserta didik untuk memformulasikan pengetahuan baru berdasarkan pengetahuan dan pengalama $\mathrm{n}$ yang telah mereka miliki sebelumnya. PROBEX menantang peserta didik untuk berfikir dan memberikan kepuasan dalam taraf tertentu apabila prediksi peserta didik sesuai dengan hasil pengamatan. Pengelolaan kelas yang baik akan melahirkan interaksi belajar mengajar yang baik pula. 


\section{EDUCATOR : Jurnal Inovasi Tenaga Pendidik dan Kependidikan Vol. 1 No. 2 Desember 2021, e-ISSN : 2807-8659 | p-ISSN : 2807-8829}

Dengan menggunakan model pembelajaran PROBEX diharapkan agar pembelajaran fisika lebih menarik dan tentunya menambah kemudahan dalam pemahaman pelajaran kepada para peserta didik. Berdasarkan dengan masalah tersebut, maka penulis melakukan perbaikan pembelajaran melalui Penelitian Tindakan Kelas (PTK) dengan rincian dua siklus untuk mata pelajaran IPA.

Belajar adalah proses perubahan tingkah laku pada diri seseorang berkat pengalaman dan pelatihan, Hilgard dan Bower (dalam Purwanto) belajar berhubungan dengan perubahan tingkah laku seseorang terhadap sesuatu situasi tertentu yang disebabkan oleh pengalamannya yang berulang-ulang dalam situasi itu, di mana perubahan tingkah laku itu tidak dapat dijelaskan dasar kecenderungan respons pembawaan, kematangan atau keadaan-keadaan sesaat seseorang. Hasil belajar secara umum diartikan adalah seberapa banyak tujuan pelajaran yang diberikan guru dapat dikuasai oleh mahasiswa, atau sejauh mana penguasaan siswa terhadap tujuan pelajaran yang telah disampaikan oleh guru, atau seberapa persen tujuan khusus dimiliki siswa dari sejumlah tujuan yang telah disampaikan. Gagne menyatakan bahwa "prestasi belajar dibedakan menjadi lima aspek, yaitu: kemampuan intelektual, strategi kognitif, informasi verbal, sikap dan keterampilan."

Menurut Bloom dalam Suharsimi Arikunto bahwa "hasil belajar dibedakan menjadi tiga aspek yaitu kognitif, afektif dan psikomotorik. Prestasi merupakan kecakapan atau hasil kongkrit yang dapat dicapai pada saat atau periode tertentu." White menyatakan bahwa PROBEX (Predict Observe Explain) adalah strategi yang sering digunakan dalam ilmu pengetahuan dan cocok untuk kontek pisik maupun dunia nyata. Strategi ini dapat digunakan untuk menemukan ide inisial siswa, meggeneralisasi lewat diskusi, menggeneralisasi lewat investigasi, serta memotivasi siswa yang ingin menyelidiki konsep. Menurut Pella \& Voelker dalam penelitian konsep perubahan fisika pada siswa sekolah dasar dengan strategi PROBEX (Predict Observe Explain) dapat meningkatkan hasil belajar bagi siswa sekolah dasar. Model pembelajaran $P R O B E X$ ini berasal dari bahasa Inggris yang merupakan kepanjanga dari Predict, Observe, and Explai.

\section{METODE PENELITIAN}

Jenis penelitian ini adalah Penelitian Tindakan Kelas (PTK) dengan menggunakan model PROBEX yang berguna untuk ketuntasan belajar siswa dan meningkatkan hasil belajar siswa dalam proses pembelajaran materi pokok tekanan. Penelitian ini dilaksanakan dalam 2 siklus, dimana setiap siklus terdiri dari empat tahapan utama sebagai berikut: (1) perencanaan (planning), (2) tindakan (acting), (3) pengamatan (observing), dan refleksi (reflecting), empat tahap kegiatan ini disebut satu siklus pemecahan masalah.

Subjek dalam penelitian ini adalah siswa kelas 8.A MTs Al Hamig Jakarta Tahun Pembelajaran 2019/2020 yang berjumlah 25 siswa. Objek penelitian ini adalah rendahnya hasil belajar siswa yang tidak mencapai nilai KKM pada mata pelajaran IPA khususnya materi konsep tekanan pada zat cair, melalui penggunaan model PROBEX untuk meningkatkan hasil belajar siswa di kelas 8.A MTs Al Hamid Jakarta. 


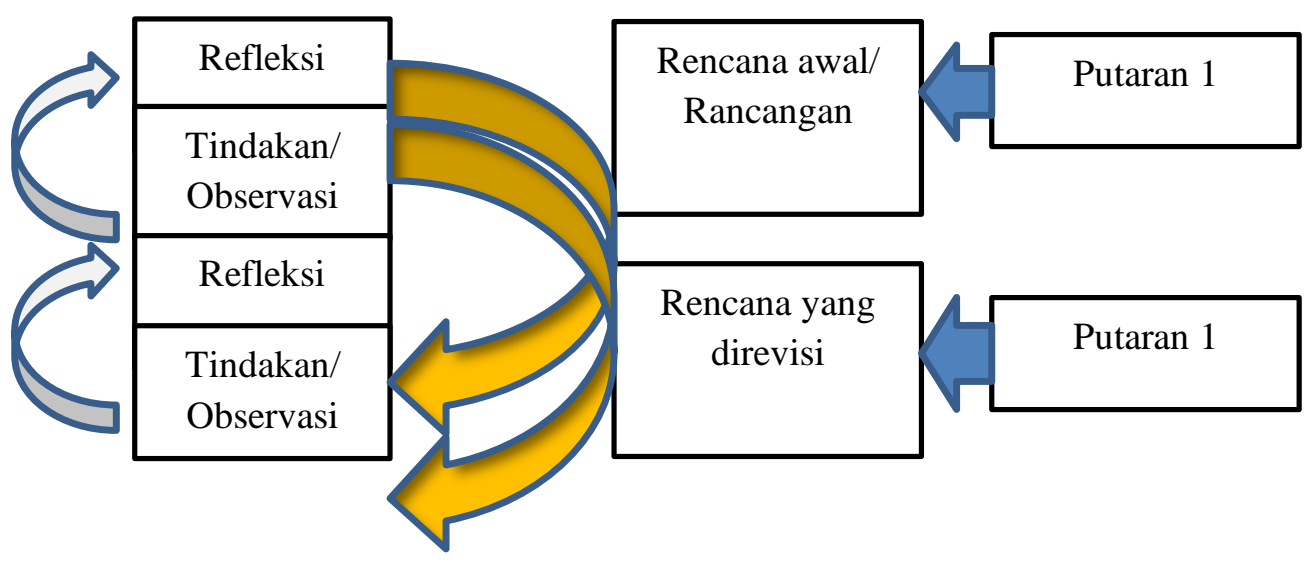

\section{Gambar 1. Alur PTK}

Penjelasan alur di atas adalah:

1) Rancangan/rencana awal, sebelum mengadakan penelitian peneliti menyusun rumusan masalah, tujuan dan membuat rencana tindakan, termasuk di dalamnya instrumen penelitian dan perangkat pembelajaran.

2) Kegiatan dan pengamatan,

3) Refleksi,

4) Rancangan/rencana yang direvisi

Untuk pengumpulan data dalam penelitian ini dilakukan dengan tes, dan lembar pengamatan atau lembar observasi. Teknik analisis data merupakan proses mengatur urutan data, mengorganisasi data ke dalam pola-pola atau kategori uraian dasar.

\section{HASIL DAN PEMBAHASAN}

\section{Hasil}

1. Pra Siklus

Penelitian ini diawali dengan pengamatan yang dilakukan oleh peneliti selama kurang lebih 2 tahun terakhir ini, pembelajaran IPA di MTs Al Hamid Jakarta Timur masih menggunakan metode yang monoton, seperti metode ceramah. Sehingga pemahaman peserta didik kurang optimal akibat dari tingkat keaktifan mereka dalam pembelajaran yang masih sangat rendah. Salah satu contohnya adalah nilai ulangan harian pada materi sebelum tekanan yaitu materi pokok usaha dan energy (sebelum diadakan remidi) dengan KKM 75, dari 25 peserta didik masih ada 17 anak atau 68\% yang mendapatkan nilai dibawah 75 . Sehingga persentase peserta didik yang mencapai KKM hanya sebesar 32\%. Dari data tersebut terlihat bahwa pembelajaran belum tercapai dikarenakan oleh berbagai hal, salah satunya guru kurang berinovasi menggunakan modelmodel pembelajaran lain selain ceramah dan diskusi. Kenyataan tersebut mendorong peneliti untuk mengadakan penelitian untuk meningkatkan hasil belajar peserta didik melalui penggunaan model pembelajaran PROBEX. Penelitian dilaksanakan dalam 2 siklus.

\section{Siklus I}

Dalam siklus I pelaksanaan perbaikan pembelajaran yang direncanakan difokuskan pada penerapan model pembelajaran PROBEX, sebagai upaya meningkatkan pemahaman materi tekanan oleh siswa.

a. Tahap Perencanaan

1) Mengidentifikasi masalah yang timbul selama proses pembelajaran pada materi pokok tekanan, yaitu belum meratanya tingkat keaktifan siswa dalam pembelajaran.

2) Membuat rencana pembelajaranan yang berisikan langkah-langkah penggunaan model PROBEX pada materi pokok tekanan. Penyusunan secara mandiri dan setelah itu dikonsultasikan dengan kolaborator sebagai observer.

3) Mempersiapkan sarana pembelajaran yang mendukung terlaksananya tindakan penelitian berupa alat dan bahan untuk eksperimen, yaitu:plastisin (karena keadaan 
kemudian diganti dengan tanah yang becek), bandul timbangan, balok kayu dan penggaris.

4) Mempersiapkan instrument penilaian, yaitu alat evaluasi berupa tes, tes berjumlah 10 soal berbentuk soal pilihan ganda untuk mengetahui hasil belajar dan lembar observasi aktivitas guru dan lembar observasi siswa.

5) Membuat Kriteria Penilaian, yaitu: siswa dikatakan tuntas ketika mencapai nilai ketuntasan minimal pada mata pelajaran IPA, yaitu 75

b. Tahap Pelaksanaan (Tindakan)

Tahap pelaksanaan dalam siklus ini dilakukan dalam satu pertemuan (2X40') pada hari selasa tanggal 14 Maret 2020dengan urutan langkah- langkah:

1) Kegiatan pendahuluan

a. Apersepsi

Guru menanyakan kepada siswa : mana jejak kaki diatas tanah yang becek yang lebih dalam ketika ada ayam dan bebek berjalan?

b. Motivasi

Guru menyampaikan kepada siswa akan pentingnya belajar - Guru menyampaikan tujuan pembelajaran

2) Kegiatan inti

a. Eksplorasi

Guru membimbing peserta didik dalam pembentukan kelompok , tiap kelompok beranggotakan maksimal 5 siswa

b. Elaborasi

(1) Guru membagikan lembar kerja siswa

(2) Perwakilan tiap kelompok diminta untuk mengambil alat dan bahan eksperimen

(3) Peserta didik memprediksi jawaban pertanyaan dalam LKS lewat diskusi kelompok

(4) Guru membimbing peserta didik membuktikan prediksi mereka dengan melakukan eksplorasi lewat eksperimen

(5) Peserta didik menuliskan hasil eksperimen dan membandingkannya dengan prediksi mereka dilembar kerja

(6) Peserta didik mempresentasikan hasil diskusi kelompok secara klasikal

(7) Guru menanggapi hasil diskusi kelompok peserta didik dan memberikan informasi yang sebenarnya

(8) Peserta didik memperhatikan contoh soal menentukan tekanan dari suatu benda padat yang disampaikan oleh guru

c. Konfirmasi

(1) Guru bertanya jawab tentang hal-hal yang belum diketahui siswa

(2) Guru bersama siswa bertanya jawab meluruskan pemahaman, memberikan penguatan dan penyimpulan

3) Kegiatan penutup

a. Guru memberikan penghargaan kepada kelompok yang memiliki kinerja dan kerjasama yang baik

b. Peserta didik (dibimbing guru) berdiskusi untuk membuat rangkuman

c. Guru memberikan soal sebagai evaluasi

c. Tahap Pengamatan

Dalam pelaksanaan tindakan dilakukan oleh peneliti sebagai guru di kelas dan dibantu oleh observer sebagai pengamat. Pengamatan yang dilakukan oleh observer adalah untuk mengamati perkembangan proses belajar mengajar yang yang dilakukan oleh guru dan keaktifan siswa dalam proses belajar yang sedang berlangsung, apakah ada kemajuan atau tidak. 


\section{d. Tahap Refleksi}

Pada tahap ini peneliti dan kolaborator sebagai observer merefleksikan kegiatan pembelajaran yang baru berlangsung dan mengkaji berbagai hal yang terjadi dan seharusnya dilakukan dalam pelaksanaan tindakan metode eksperimen pada siklus I.

Adapun temuan hasil refleksi adalah: 1. Pelaksanaan pembelajaran sudah sesuai RPP 2. Suasana kelas kondusif dan terkendali 3. Pemberian motivasi kepada siswa kurang mengena 4. Pembagian kelompok praktikum dan diskusi kurang homogen (belum merata) 5. Tingkat keaktifan siswa dalam pembelajaran sudah meningkat dari biasanya saat penggunaan metode konvensional walaupun belum merata karena masih didominasi oleh siswa tertentu 6. Pembimbingan dalam eksperimen dan diskusi sudah bagus. Pemberian penguatan diakhir pembelajaran sudah bagus 8 . Persiapan untuk praktikum (alat dan bahan) kurang matang.

Walaupun masih terdapat kekurangan dalam pelaksanaan pembelajaran dengan model PROBEX, ternyata perolehan nilai dan persentase ketuntasan belajar siswa meningkat. Pada pembelajaran yang dilaksanakan sebelum perbaikan terlihat bahwa persentase ketuntasan belajar hanya mencapai $32 \%$ pada perbaikan pembelajaran I menjadi $64 \%$ sehingga terlihat ada peningkatan $32 \%$, seperti pada tabel 1

Tabel 1. Data hasil tes akhir Siklus I

\begin{tabular}{|c|l|c|}
\hline No. & \multicolumn{1}{|c|}{ Deskripsi } & Keterangan \\
\hline 1 & Nilai Tertinggi & 85 \\
\hline 2 & Nilai Terendah & 60 \\
\hline 3 & Nilai rata-rata & 75,2 \\
\hline 4 & Ketuntasan & $64 \%$ \\
\hline
\end{tabular}

Meskipun data menunjukkan adanya peningkatan belajar sebesar 32\%, yaitu dari sebelum perbaikan sebesar 32\% menjadi 64\% namun sepenuhnya pembelajaran pada siklus I belum sepenuhnya berhasil. Sebab batas minimal ketuntasan belajar adalah $75 \%$. Oleh karenanya peneliti berupaya memperbaiki pembelajaran pokok bahasan tekanan.

\section{Siklus II}

Sehubungan masih kurang berhasilnya pembelajaran pada perbaikan pembelajaran siklus I maka peneliti berupaya menemukan faktor penyebab kekurangberhasilan pembelajaran pada siklus I. Dari kegiatan refleksi dan diskusi dengan teman sejawat, serta bantuan dari observer, ditemukan faktor penyebabnya, yaitu penggunaan model pembelajaran PROBEX yang kurang optimal. Selanjutnya peneliti memfokuskan penelitian perbaikan pembelajaran dengan model PROBEX yang lebih optimal.

a. Tahap Perencanaan

1) Mengidentifikasi masalah yang timbul pada proses perbaikan pembelajaran siklus I dan hasilnya ternyata hasil belajar siswa masih rendah.

2) Merancang Rencana Perbaikan Pembelajaran 2 yang dibuat secara mandiri dan dikonsultasikan dengan kolaborator.

3) Mempersiapkan sarana pembelajaran yang mendukung terlaksananya tindakan penelitian berupa alat dan bahan untuk eksperimen yaitu botol aqua bekas berukuran $600 \mathrm{ml}$,air , oli bekas dan penggaris

4) Membuat lembar observasi guru dan siswa serta test evaluasi berjumlah 10 soal pilihan ganda terhadap materi pembelajaran

b. Tahap Tindakan

Tahap pelaksanaan dalam siklus ini dilakukan dalam satu pertemuan (2X40') pada hari Sabtu tanggal 3 April 2020 jam ke 3-4 (08.25-09.50 WIB) dengan urutan langkahlangkah: 
1) Kegiatan pendahuluan

(a) Apersepsi

Guru memberikan pertanyaan kepada siswa: mengapa pada kaleng yang ringsek yang diisi air dan dilubangi, air akan keluar dari tiap lubang ?

(b) Motivasi

Guru menyampaikan kepada siswa akan pentingnya mempelajari tekanan pada zat cair - Guru menyampaikan tujuan pembelajaran

2) Kegiatan inti

(a) Eksplorasi

(1) Guru membimbing peserta didik dalam pembentukan kelompok , tiap kelompok beranggotakan maksimal 5 siswa

(2) Guru mengingatkan kepada peserta didik untuk berhati-hati dan cermat dalam melakukan eksperimen

(b) Elaborasi

(1) Guru membagikan lembar kerja siswa

(2) Perwakilan tiap kelompok diminta untuk mengambil alat dan bahan eksperimen

(3) Peserta didik memprediksi jawaban dari pertanyaan dalam LKS - Guru mempresentasikan langkah kerja untuk melakukan eksperimen mengamati tekanan dalam zat cair

(4) Peserta didik dalam setiap kelompok melakukan eksperimen sesuai dengan langkah kerja yang telah dijelaskan guru

(5) Guru memperiksa eksperimen yang dilakukan peserta didik, apakah sudah dilakukan dengan benar atau belum. Jika peserta didik atau kelompok ada yang belum melakukannya denga benar, guru dapat langsung memberikan bimbingan

(6) Peserta didik menuliskan hasil eksperimen dan membandingkannya dengan prediksi mereka dilembar kerja

(7) Peserta didik mempresentasikan hasil diskusi kelompok secara klasikal

(8) Guru menanggapi hasil diskusi kelompok peserta didik dan memberikan informasi yang sebenarnya.

(9) Peserta didik memperhatikan contoh soal menentukan tekanan dalam zat cair yang disampaikan guru

(c) Konfirmasi

(1) Guru bertanya jawab tentang hal-hal yang belum diketahui siswa

(2) Guru bersama siswa bertanya jawab meluruskan kesalahan pemahaman, memberikan penguatan dan penyimpulan

3) Kegiatan penutup

(a) Guru memberikan penghargaan kepada kelompok yang memiliki kinerja dan kerja sama yang baik

(b) Peserta didik (dibimbing guru) berdiskusi untuk membuat kesimpulan

(c) Guru memberikan soal sebagai bahan evaluasi.

c. Tahap Observasi (Pengamatan)

Observasi terhadap pelaksanaan tindakan siklus I dan siklus II dengan menggunakan lembar observasi yang telah dibuat. Peneliti mengajar di kelas sedangkan seorang guru yang lain sebagai observer mengisi lembar observasi untuk mengamati kegiatan yang terjadi selama proses belajar mengajar berlangsung melalui penggunaan model PROBEX dengan tujuan untuk mengobservasi kemajuan dan kelamahan siswa.

d. Tahap Refleksi

Pada siklus II peneliti dan pengamat sebagai observer merefleksikan pembelajaran yang baru berlangsung untuk melihat dan mengetahui apakah masih 
terdapat kesulitan memahami materi ataupun kesulitan dalam menyelesaikan masalah yang berkenaan dengan materi pokok tekanan.

Adapun temuan hasil refleksi pada siklus ini adalah:

1) Perbaikan pelaksanaan sudah sesuai rencana

2) Persiapan pelaksanaan sudah lebih matang

3) Pemberian motivasi kepada siswa sudah bagus dan mengena

4) Pembagian kelompok diskusi sudah lebih merata dan homogen

5) Tingkat keaktifan siswa dalam pembelajaran meningkat dengan signifikan

6) Pemberian penguatan diakhir sudah bagus

Ternyata pada siklus 2 ini hasil belajar sangat meningkat sekali dan sudah mencapai batas ketuntasan belajar siswa, seperti ditunjukkan pada tabel 2. Oleh karena itu penelitian dilakukan hanya sampai siklus II saja

Tabel 2. Data hasil tes akhir Siklus II

\begin{tabular}{|c|l|c|}
\hline No. & \multicolumn{1}{|c|}{ Deskripsi } & Keterangan \\
\hline 1 & Nilai Tertinggi & 90 \\
\hline 2 & Nilai Terendah & 65 \\
\hline 3 & Nilai rata-rata & 79 \\
\hline 4 & Ketuntasan & $92 \%$ \\
\hline
\end{tabular}

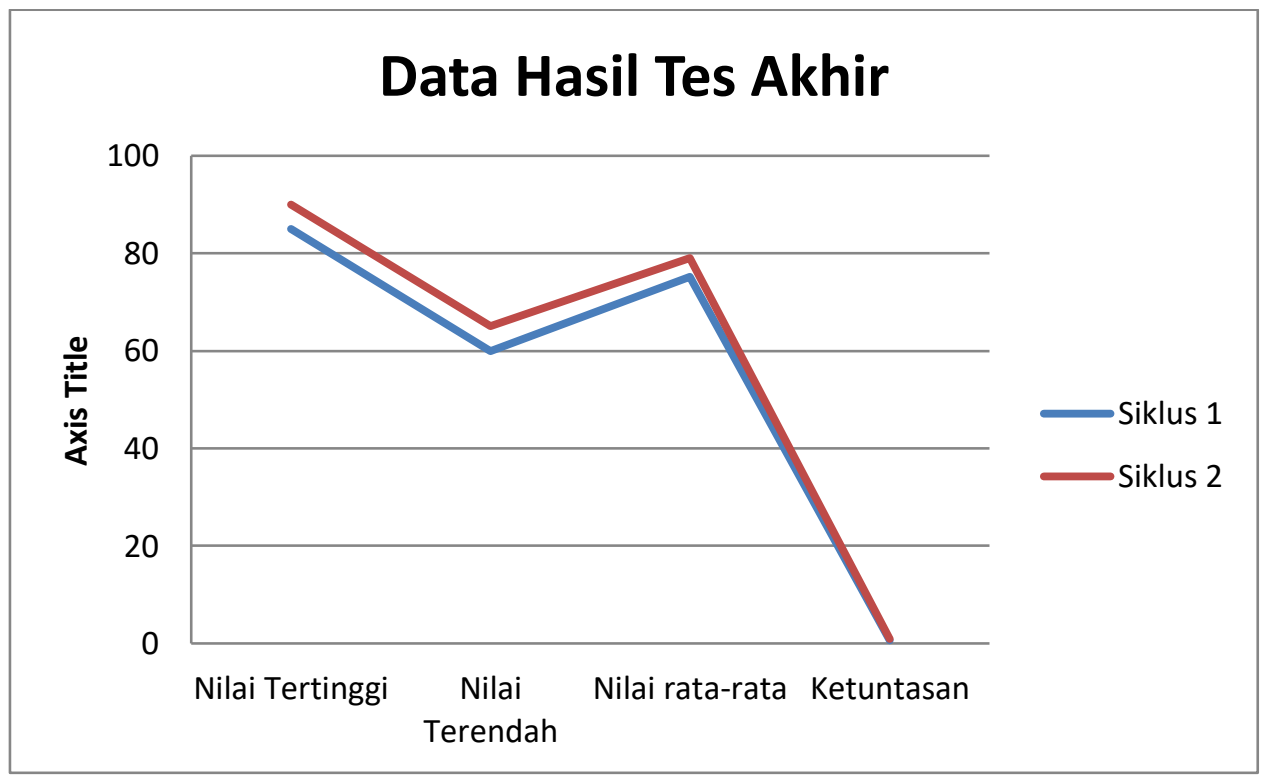

Gambar 2. Grafik perbandingan siklus 1 dan 2

\section{Pembahasan}

1. Kognitif

Fokus perbaikan pembelajaran pada siklus I adalah penerapan model pembelajaran PROBEX. Model ini merupakan penerapan metode yang menggambarkan kerjasama dengan siswa aktif dalam kegiatan pembelajaran, yaitu guru memberikan permasalahan, siswa dibimbing guru memprediksi pemecahan permasalahan. Jadi dominasi guru dalam proses pembelajaran menjadi berkurang dan siswa terlibat aktif dalam proses pembelajaran. Pada kegiatan inti siswa secara berkelompok dengan bimbingan guru memecahkan permasalahan yang berkaitan dengan faktor-faktor yang mempengaruhi tekanan, kemudian dibahas. Guru selalu berusaha mengoptimalkan interaksi antar siswa atau antara siswa dengan guru melalui kegiatan kelompok. Siswa terlibat aktif dalam proses pembelajaran melalui kegiatan diskusi kelompok ataupun diskusi kelas. Pada akhir pembelajaran guru memberikan evaluasi untuk mengetahui tingkat pemahaman siswa terhadap materi yang diajarkan. 
Perbaikan pembelajaran pada siklus I menunjukkan adanya peningkatan baik peran guru, persentase pembelajaran maupun persentase ketuntasan belajar. Namun demikian hasil belajar siswa belum maksimal. Dari kegiatan refleksi teridentifikasi bahwa yang menjadi kendalanya adalah kurang optimalnya penerapan model PROBEX dalam pembelajaran, terutama peran serta siswa secara aktif dalam pembelajaran belum maksimal.

Selanjutnya pada siklus II penelitian perbaikan pembelajaran, difokuskan pada penerapan model pembelajaran PROBEX yang lebih optimal. Selama proses pembelajaran, siswa tampak lebih proaktif. Hasilnya ketuntasan belajar siswa mencapai 92\% meskipun belum dapat mencapai $100 \%$, namun dapat dikatakan bahwa siswa telah mencapai ketuntasan belajar sebab telah memenuhi standar ketuntasan belajar 75\%. Sampai pada perbaikan pembelajaran siklus II, masih ditemukan beberapa siswa dalam satu kelas yang belum berhasil mencapai nilai tuntas. Hal ini disebabkan karena daya serap siswa terhadap materi sangat rendah, dan motivasi belajarnya kurang. Secara keseluruhan hasil belajar siswa adalah sebagai berikut.

Tabel 3. Hasil Belajar Siswa Secara Keseluruhan

\begin{tabular}{|c|c|c|c|c|c|}
\hline No & Nama Siswa & $\begin{array}{l}\text { Pra } \\
\text { Siklus }\end{array}$ & $\begin{array}{l}\text { Siklus } \\
\text { I }\end{array}$ & $\begin{array}{c}\text { Siklus } \\
\text { II }\end{array}$ & Ketuntasan \\
\hline 1 & Agnia Sabila & 70 & 80 & 90 & Tuntas \\
\hline 2 & Alifvia Majisah Putri & 80 & 80 & 80 & Tuntas \\
\hline 3 & Alisya Putri & 75 & 85 & 85 & Tuntas \\
\hline 4 & $\begin{array}{l}\text { Andrea Hanifa } \\
\text { Salsabilla }\end{array}$ & 80 & 85 & 85 & Tuntas \\
\hline 5 & Aryani Wahyu Lestari & 60 & 70 & 80 & Tuntas \\
\hline 6 & Cut Ghzya Adnanny & 67.5 & 65 & 65 & $\begin{array}{l}\text { Tidak } \\
\text { Tuntas }\end{array}$ \\
\hline 7 & Delmora Hilda Rizkia & 83 & 85 & 85 & Tuntas \\
\hline 8 & $\begin{array}{l}\text { Dwi Septiana } \\
\text { Nurcahyani }\end{array}$ & 60 & 80 & 80 & Tuntas \\
\hline 9 & $\begin{array}{l}\text { Ficky Aulia Zakia } \\
\text { Mecca }\end{array}$ & 52 & 75 & 75 & Tuntas \\
\hline 10 & Fitriyah Mutiara Injaya & 70 & 80 & 80 & Tuntas \\
\hline 11 & Halimah Athaya & 55 & 75 & 85 & Tuntas \\
\hline 12 & Ihyatul Musyarrofah & 60 & 80 & 80 & Tuntas \\
\hline 13 & Inayatul Fuana & 75 & 75 & 75 & Tuntas \\
\hline 14 & $\begin{array}{l}\text { Khansa Nadia Alifah } \\
\text { Rosady }\end{array}$ & 70 & 80 & 80 & Tuntas \\
\hline 15 & Lovya Andira & 80 & 80 & 80 & Tuntas \\
\hline 16 & Nabilah Fadil Alhamid & 55 & 65 & 75 & Tuntas \\
\hline 17 & Nanda Ardelia Setiawan & 78 & 85 & 85 & Tuntas \\
\hline 18 & $\begin{array}{l}\text { Naura Novri Intania } \\
\text { Khaerunnisa }\end{array}$ & 55 & 60 & 75 & Tuntas \\
\hline 19 & $\begin{array}{l}\text { Naysilla Fatikhah } \\
\text { Azahra }\end{array}$ & 60 & 70 & 75 & Tuntas \\
\hline 20 & Novriyati Nur Fajri & 68 & 75 & 75 & Tuntas \\
\hline 21 & Raisha Sittah Az Zahrah & 55 & 75 & 80 & Tuntas \\
\hline 22 & $\begin{array}{l}\text { Ryke Nisfa Annisa } \\
\text { Sholeha }\end{array}$ & 60 & 65 & 70 & $\begin{array}{l}\text { Tidak } \\
\text { Tuntas }\end{array}$ \\
\hline 23 & $\begin{array}{l}\text { Salsa Aisyaro An'nur } \\
\text { Sya'ban }\end{array}$ & 65 & 70 & 75 & Tuntas \\
\hline 24 & Selaras Dinanti Widyani & 80 & 70 & 80 & Tuntas \\
\hline
\end{tabular}


EDUCATOR : Jurnal Inovasi Tenaga Pendidik dan Kependidikan Vol. 1 No. 2 Desember 2021, e-ISSN : 2807-8659 | p-ISSN : 2807-8829

\begin{tabular}{|r|r|c|c|c|c|}
\hline No & \multicolumn{1}{|c|}{ Nama Siswa } & Pra & Siklus & Siklus & \\
\hline \multirow{2}{*}{25} & $\begin{array}{l}\text { Tasya Ramadhania } \\
\text { Pratiwi Hartono }\end{array}$ & 60 & 70 & 80 & Tuntas \\
\hline \multirow{4}{*}{ Nilai rata-rata } & 66.9 & 75.2 & 79.0 & \\
\cline { 2 - 6 } & Tuntas & 8 & 16 & 23 & \\
\cline { 2 - 6 } & Belum tuntas & 17 & 9 & 2 & \\
\cline { 2 - 6 } & \% Ketuntasan Belajar & 32.00 & 64.00 & 92.00 & \\
\cline { 2 - 6 }
\end{tabular}

\section{Aktivitas Belajar}

Perolehan tingkat keaktifan siswa pada siklus I masih belum optimal yaitu hanya sebesar $62 \%$. Siswa yang aktif dalam pembelajaran belum merata, hanya siswa tertentu saja yang sudah aktif dalam pembelajaran dan siswa yang aktif itu pun sebagian besar merupakan siswa yang sudah aktif sebelum dilakukan tindakan dan juga merupakan siswa dengan tingkat kemampuan akademik tinggi. Siswa yang belum aktif dalam pembelajaran salah satunya disebabkan karena meraka masih merasa takut salah dan malu untuk bertanya, menjawab pertanyaan atau mengemukakan pendapat. Kurang optimalnya keaktifan siswa pada siklus I juga disebabkan karena siswa belum terbiasa melakukan kegiatan pembelajaran dengan model pembelajaran PROBEX. Kerjasama antar anggota kelompok belum tampak nyata. Kegiatan siswa dalam kelompok masih didominasi oleh siswa yang kemampuan akademiknya tinggi. Siswa yang kurang pandai belum percaya diri untuk mengemukakan pendapatnya dalam kegiatan diskusi. Siswa tampaknya masih perlu berlatih untuk mengemukakan pendapat dan menumbuhkan sikap percaya diri. Hal ini sesuai dengan pendapat Lie (2004:28) yang menyatakan bahwa keterampilan berkomunikasi dalam kelompok, terutama saat memberikan penjelasan (explain) ini juga merupakan proses panjang. Pendapat yang serupa juga disampaikan Ibrahim bahwa pembelajaran PROBEX memerlukan waktu lebih lama bagi siswa untuk berinteraksi mengenai ide-ide secara langsung kepada siswa lain dalam melakukan pengamatan terhadap percobaan yang dilaksanakan maupun dalam memberikan penjelasan terhadap apa yang diamati.

Belum optimalnya peran siswa dalam pembelajaran juga berdampak pada kurangnya tingkat pemahaman siswa terhadap materi yang dipelajari. Pada siklus I ini siswa yang tuntas belajar baru mencapai $64 \%$ dengan nilai rata-rata 75,2. siswa yang turut aktif dalam menemukan konsep tentang materi yang dipelajari akan lebih mudah paham dan mengerti dibandingkan dengan siswa yang hanya sekedar melihat dan mengamati. Metode PROBEX dapat meningkatkan sikap ilmiah dan prestasi belajar kimia siswa. Rasa ingin tahu, sikap berpikir kritis, dan kerjasama merupakan bagian dari karakter sikap ilmiah (Puriyandari,Saputro, \& Masykuri ,2014).

\section{KESIMPULAN}

Berdasarkan hasil penelitian dan pembahasan dapat ditarik beberapa kesimpulan bahwa "Penerapan Model PROBEX dapat meningkatkan hasil belajar IPA pada materi pokok Tekanan Zat pada siswa kelas 8.A MTs Al Hamid Jakarta Timur Tahun Pelajaran 2019/2020, yaitu sebelum perbaikan ketuntasan hanya 32\%, setelah siklus I mencapai $64 \%$ dan setelah pelaksanaan siklus II mencapai $92 \%$.

\section{DAFTAR PUSTAKA}

Aqib, Z. (2012). Model-model, Media dan Strategi Pembelajaran Kontekstual, Bandung: Yrama Widya

Arikunto, S. (2006). Penelitian Tindakan Kelas, Jakarta, Bumi Aksara Arikunto, Suharsimi. 2008. Evaluasi Pendidikan, Jakarta: Rineka Cipta

Hamalik, O. (2010). Psikologi Belajar Mengajar, Jakarta: Sinar Baru Algesindo

Isjoni. (2007). Cooperative Learning, Jakarta: Rajawali Press Purwanto, 
Roestiyah N.K. (2006). Strategi Belajar Mengajar, Jakarta: Rineka Cipta

Sardiman A.M. (2009). Interaksi dan Motivasi Belajar Mengajar, Jakarta: Rineka Cipta

Supardi. (2006). Penelitian Tindakan Kelas. Jakarta: Rineka Cipta

Sutanto, A. (2008). Pembelajaran Konstruktivisme. Semarang : Balai Penataran Guru Semarang

Trianto. (2010). Pembelajaran Konstruktivistik dalam IPA, Malang: Pustaka Media

Lestari, Sifi. (2017). Keefektifan Model Pembelajaran PROBEX Berbantuan Lembar Kerja Siswa Terhadap Pencapaian Kompetensi Siswa Kelas XI SMA Negeri AJIBARANG. Diss. Universitas Negeri Semarang,

Ghony, M. Djunaidi. (2008). Penelitian tindakan kelas. UIN-Maliki Press, Malang.

Maya Sih Hika Pamungkas., Sri Mulyani., Sulistyo Saputro. (2017). Penerapan Model Pembelajaran POE Dengan Metode Praktikum Untuk Meningkatkan Rasa Ingin Tahu Dan Prestasi Belajar Kimia Siswa. Jurnal Penelitian Pendidikan, Vol. 20 No. 1 